\title{
A Pathogenetic Role for the Thymoma in Myasthenia Gravis Autosensitization of IL-4-producing T Cell Clones Recognizing Extracellular Acetylcholine Receptor Epitopes Presented by Minority Class II Isotypes
}

\author{
Nita Nagvekar, ${ }^{*}$ Anne-Marie Moody, ${ }^{*}$ Paul Moss, ${ }^{\ddagger}$ loannis Roxanis, ${ }^{*}$ John Curnow, ${ }^{*}$ David Beeson, ${ }^{*}$ Nadia Pantic, \\ John Newsom-Davis, ${ }^{*}$ Angela Vincent, ${ }^{*}$ and Nicholas Willcox* \\ *Neuroscience Group and ${ }^{\ddagger}$ Department of Molecular Immunology, Institute for Molecular Medicine, University of Oxford, OX3 9DS, \\ United Kingdom
}

\begin{abstract}
Myasthenia gravis (MG) is caused by helper T cell-dependent autoantibodies against the muscle acetylcholine receptor (AChR). Thymic epithelial tumors (thymomas) occur in $10 \%$ of MG patients, but their autoimmunizing potential is unclear. They express mRNAs encoding AChR $\alpha$ and $\epsilon$ subunits, and might aberrantly select or sensitize developing thymocytes or recirculating peripheral $T$ cells against AChR epitopes. Alternatively, there could be defective selftolerance induction in the abundant maturing thymocytes that they usually generate. For the first time, we have isolated and characterized AChR-specific T cell clones from two MG thymomas. They recognize extracellular epitopes ( $\alpha 75-90$ and $\alpha 149-158)$ which are processed very efficiently from muscle AChR. Both clones express CD4 and CD8 $\alpha$, and have a Th- 0 cytokine profile, producing IL- 4 as well as IFN- $\gamma$. They are restricted to HLA-DP14 and DR52a; expression of these minority isotypes was strong on professional antigen-presenting cells in the donors' tumors, although it is generally weak in the periphery. The two clones' $T$ cell receptor $\beta$ chains are different, but their $\alpha$ chain sequences are very similar. These resemblances, and the striking contrasts with $T$ cells previously cloned from nonthymoma patients, show that thymomas generate and actively induce specific $T$ cells rather than merely failing to tolerize them against self antigens. (J. Clin. Invest. 1998. 101:2268-2277.) Key words: paraneoplastic autoimmunity • thymic epithelium - autoimmune T cells - HLA-DR isotypes $\cdot$ HLA-DP
\end{abstract}

\section{Introduction}

Very little is known about the initiation of most autoimmune diseases, but some of them regularly associate with particular tumors $(1,2)$. For example, $\sim 5 \%$ of patients with epithelial

Address correspondence to Dr. Nicholas Willcox, Neurosciences Group, Institute for Molecular Medicine, John Radcliffe Hospital, University of Oxford, OX3 9DS, United Kingdom. Phone: 441865-222-325; FAX: 44-1865-222-402; E-mail: neurosciences@imm. ox.ac.uk P. Moss' present address is Department Haematology, Medical School, University of Birmingham, B15 2TJ, United Kingdom.

Received for publication 23 October 1997 and accepted in revised form 12 March 1998.

J. Clin. Invest.

(C) The American Society for Clinical Investigation, Inc. 0021-9738/98/05/2268/10 \$2.00

Volume 101, Number 10, May 1998, 2268-2277

http://www.jci.org thymomas have autoimmune bone marrow aplasias or neuromyotonia, and around one third develop myasthenia gravis $(\mathrm{MG}),{ }^{1}$ a classic autoantibody-mediated disorder $(3,4)$. All MG patients with thymoma have antibodies to the extracellular domain of the acetylcholine receptor (AChR) that are responsible for their muscle weakness (4). This well-characterized autoantigen comprises $\alpha_{2}, \beta, \gamma$, and $\delta$ subunits in the human fetus and $\alpha_{2}, \beta, \epsilon$, and $\delta$ subunits in the adult, all of which have been cloned and sequenced (5). These patients also have other autoantibodies to a range of striational muscle antigens, including actin, myosin (6), and, most frequently, titin (7).

One general hypothesis to explain the link between thymomas and autoimmune disease is that autoantigenic epitopes expressed on the neoplastic epithelial cells positively select helper $\mathrm{T}$ cells maturing in the tumors, or actively sensitize either their progeny or recirculating peripheral T cells (4). An alternative theory is that, since the thymomas usually generate numerous thymocytes in a disorganized thymic cortical environment (8), they might merely fail to delete or tolerize potentially self-reactive T cells (9). In either case, since B cells are generally rare in thymomas (8), it is likely that the T cells subsequently initiate autoantibody responses in the periphery.

The first hypothesis depends on the presence of autoantigen in the thymoma. Whereas some striational epitopes have been detected in these tumors $(10,11)$, evidence for expression of AChR in these cells is conflicting. Monoclonal antibodies (mAbs) against the extracellular AChR epitopes that are recognized by MG autoantibodies (12) do not label thymoma tissue (13), indicating that the whole pentameric AChR is not expressed. Nevertheless, mRNAs for individual AChR subunits have been detected in thymoma tissue by PCR (14-16), and for the adult-specific $\epsilon$ subunit by less sensitive RNAase protection assays (MacLennan, C., D. Beeson, N. Willcox, A. Vincent, and J. Newsom-Davis, manuscript in preparation). Moreover, one group of mAbs against $\alpha 371-380$ of the cytoplasmic loop of the AChR $\alpha$ subunit bind to the neoplastic epithelial cells (13), although they are apparently cross-reacting with a neurofilament protein $(17,18)$. Since helper T cells might thus be sensitized by epitopes processed from individual subunits in these thymomas, their characterization should help to identify the original immunogen.

As yet, very few T cells with rigorously proven AChR- and AChR peptide-specificity have been characterized from MG patients in general (19), and none from those with thymomas,

1. Abbreviations used in this paper: $\mathrm{AChR}$, acetylcholine receptor; APC, antigen-presenting cell(s); MG, myasthenia gravis; MIR, main immunogenic region; PBLx, 30 Gy-irradiated PBL; PPD, purified protein derivative (of tuberculin); PVS, perivascular space; TCR, T cell receptor(s). 
although they are apparently enriched in these tumors (20). Here, we have characterized AChR-specific T cells from two MG thymomas, after selecting $\mathrm{T}$ cell lines and clones against the full-length recombinant human $\alpha$ subunit which until this point was believed to be the immunodominant subunit (21). These $T$ cells are remarkably similar in their surface phenotype, T cell receptor (TCR) V $\alpha$ sequence, and cytokine profile. Moreover, they both prove to recognize extracellular epitopes from whole AChR presented by minority class II molecules that were expressed most strongly on professional antigen-presenting cells (APC) in the donor thymomas. Thus, these observations favor the first hypothesis of active selection or sensitization in the thymoma.

\section{Methods}

Antigens. AChR solubilized from human calf muscle or Torpedo electric organs in Triton X-100 was affinity-purified on $\alpha$-neurotoxin columns, dialyzed against $0.1 \%$ cholate, and captured onto immunomagnetic beads (Dynal, Oslo, Norway) as previously described (22). Recombinant AChR $\alpha$-subunit polypeptides of varying lengths ( $\mathrm{r} 1-$ 437, etc.) were expressed in Escherichia coli and purified by preparative SDS-PAGE $(23,24)$. Peptides were synthesized using F-moc chemistry on LKB Biolynx apparatus (24). Purified protein derivative (PPD) of Mycobacterium tuberculosis and PHA were purchased from Evans Medical Co. (Leatherhead, England) and Difco Laboratories, Inc. (Detroit, MI), respectively.

Patients and cells. Fresh samples of thymomas and PBL were obtained with informed consent from 18 patients with typical clinical and electromyographic features of $\mathrm{MG}$ and raised serum anti-AChR titers. The clinical features of the two responder patients TA and TB are summarized in Table I; of the others, only 4 of 14 had similarly short MG durations $(<8 \mathrm{mo})$. Thymoma cell suspension was prepared by mechanical disruption. In TB, this had clearly been enriched in APC and mature $\mathrm{CD}^{+} \mathrm{T}$ cells by the prior corticosteroid pretreatment (8) and was used on the day of surgery. From TA, a low density fraction was prepared from cryostored thymoma cells on $3 \%$ ficoll/ $10 \%$ sodium metrizoate; it was similarly enriched in mature/activated $\mathrm{T}$ cells and class $\mathrm{II}^{+}$cells, and was used in cocultures with fresh irradiated autologous PBL (PBLx; reference 20).

Monolayer cultures were established from thymoma TB in DME/ $5 \%$ FCS plus insulin $(10 \mu \mathrm{g} / \mathrm{ml})$ hydrocortisone $(0.5 \mu \mathrm{g} / \mathrm{ml})$ and EGF $(10 \mathrm{ng} / \mathrm{ml})$, and cholera toxin subunit A $(50 \mathrm{ng} / \mathrm{ml}$; all from SigmaAldrich Chemie GmbH, Deisenhofen, Germany) to inhibit fibroblasts; these latter were cultured separately in DME/5\% FCS alone. After 6 $\mathrm{wk},>95 \%$ pure epithelial or fibroblast lines (as judged by double immunofluorescence staining with mAbs to cytokeratin [LP34] and fibronectin [MAS 037b]) were cryostored for subsequent use as APC.

$T$ cell lines and clones. To initiate $\mathrm{T}$ cell lines from patient TA, thymoma cells plus 30 Gy-irradiated PBL (PBLx, $2.5 \times 10^{6} / \mathrm{ml}$ each) were cultured with recombinant AChR $\alpha$-subunit (r37-429 at $0.5 \mu \mathrm{g} / \mathrm{ml}$ ) at $37^{\circ} \mathrm{C}$ in $5 \% \mathrm{CO}_{2}$ in humidified air in RPMI 1640 (Sigma Chemical Co., Ltd., Poole, United Kingdom) plus $5 \% \mathrm{~A}^{+}$human serum for $6 \mathrm{~d}$ $(20,24,25)$. The activated blast cells were enriched on Percoll gradients (20), and were expanded by addition of IL-2 $(20 \mathrm{U} / \mathrm{ml}$; Biotest, Solihull, United Kingdom) at 3-d intervals. On day 13, and at 10-14-d intervals thereafter, they were restimulated with recombinant antigen plus autologous PBLx (either fresh or cryostored), and further expanded with IL-2. This line was cloned after 5 mo of growth. From patient TB, thymoma cells were initially cultured in bulk $\left(3.10^{6}\right.$ cells in $1 \mathrm{ml})$ with $\mathrm{r} 1-437, \mathrm{r} 265-437$, or $\mathrm{r} 3-181$, and samples $\left(10^{5}\right.$ cells $)$ were pulsed with $\left[{ }^{3} \mathrm{H}\right]$ thymidine on days 5,7 , and 10 to assay responses. A parallel sample of the r3-181-stimulated line was given $20 \mathrm{U} / \mathrm{ml} \mathrm{IL-2}$ on days 4,7 , and 10 , then cloned on day 15 .

To clone $\mathrm{T}$ cell lines, limiting numbers of rested $\mathrm{T}$ cells $(0.3,3$, or 10 cells per well) were cocultured with autologous PBLx $\left(2 \times 10^{4}\right.$ per well) plus the most stimulatory antigen preparations (or PHA) plus $20 \mathrm{U} / \mathrm{ml}$ IL-2 in $20 \mu \mathrm{l}$ Terasaki wells $(24,25)$. Positive wells were expanded into $200 \mu \mathrm{l}$ and $2 \mathrm{ml}$ wells with PBLx plus antigen or PHA. No IL-4 was used at any stage before either clone was well established.

To assay responses from TA, $2 \times 10^{5}$ low density thymoma cells plus $2 \times 10^{5}$ PBLx were cultured in triplicate in round-bottomed micro wells (Nunclon; Life Technologies, Paisley, Scotland) with the indicated antigens for $72 \mathrm{~h}$, when $1 \mu \mathrm{Ci}\left[{ }^{3} \mathrm{H}\right]$ thymidine was added. After a further $18 \mathrm{~h}$, the plates were harvested and counted on a Betaplate flat-bed liquid scintillation counter (Wallac, Turku, Finland). For established $\mathrm{T}$ cell lines and clones, $2-4 \times 10^{4} \mathrm{~T}$ cells were cocultured with 1-2 $\times 10^{5}$ autologous or HLA-sharing PBLx or EBV-transformed $\mathrm{B}$ cell lines that had been pretreated with mitomycin $\mathrm{C}$ (50 $\mu \mathrm{g} / \mathrm{ml}$ for $50 \mathrm{~min}$ ) or lightly fixed with $0.025 \%$ glutaraldehyde (24). In some cases, APC were preincubated with peptides for 2-6 h (and washed) before coculture with the T cells, which otherwise were cultured with APC and antigen continuously (24). We used five B cell lines from the Xth histocompatibility workshop: KAS011 (HLA$D P A 1 * 01 / 0201 ; D P B 1 * 0401 / 1401)$; VAVY (DRB1*0301 ["DR3"]; DRB3*0101 ["DR52a"]); L0081785 (DR3; DRB3*0202 ["DR52b”]; HHKB (DRB1*1301 ["DR13"]; DR52a); and CB6B (DR13; DR52b). We also raised new $\mathrm{B}$ cell lines from TB, TA and his parents. Thymoma epithelial cells $\left(2.5 \times 10^{4}\right)$ and fibroblasts $\left(1.6 \times 10^{4}\right)$ were pretreated for $48 \mathrm{~h}$ with $500 \mathrm{IU} / \mathrm{ml}$ of IFN- $\gamma$, washed, and cocultured with $5 \times 10^{4} \mathrm{~TB}-2 \mathrm{~T}$ cells in flat-bottomed wells. Responses were assayed after $72 \mathrm{~h}$.

Cytokine production. We assayed for IFN- $\gamma$ and IL-4 in supernatants of standard proliferation assays, using ELISA kits for IL-4 (R \& D Systems, Abingdon, United Kingdom), and for IFN- $\gamma$ (Medgenix Diagnostics, Milton Keynes, United Kingdom).

Immunolabeling. We used mAbs to CD4 (RFT4) and HLA class II (RF-DRI; from Professor G. Janossy, Royal Free Hospital, London) to stain $\mathrm{T}$ cell lines/clones in suspension by indirect immunofluorescence. Cells were stained for $20 \mathrm{~min}$ at $4^{\circ} \mathrm{C}$ with either anti-CD4FITC (RFT4) plus anti-CD8 $\alpha$-phycoerythrin (DAKO A/S, Glostrup,

Table I. Clinical Details of Patients TA and TB and Responses of Their Fresh T Cells

\begin{tabular}{|c|c|c|c|c|c|c|c|c|}
\hline \multirow[b]{3}{*}{ Patient } & \multirow{2}{*}{\multicolumn{3}{|c|}{ Clinical features }} & \multirow[b]{3}{*}{ MG duration } & \multirow{3}{*}{$\frac{\text { Steroid }}{\text { Pretreatment }}$} & \multicolumn{3}{|c|}{$\mathrm{T}$ cell responses to $\mathrm{AChR}$ (S.I.) } \\
\hline & & & & & & \multirow{2}{*}{$\begin{array}{c}\text { PBL } \\
\alpha 1-437\end{array}$} & \multicolumn{2}{|c|}{ Thymoma } \\
\hline & Onset age & anti-AChR titer & MG grade & & & & $\alpha 1-437$ & $\alpha 3-181$ \\
\hline & $y r$ & $n M o l$ & & mo & & & & \\
\hline Patient TA & 17 & 34.4 & Severe generalized & 3 & - & 2.1 & 7.7 & 9.3 \\
\hline Patient TB & 43 & $>34.4$ & Moderate generalized & 3 & $4 \mathrm{wk}$ & 1.3 & 1.3 & 8.4 \\
\hline
\end{tabular}

The response of the $\mathrm{T}$ cells is expressed as stimulation index (S.I.) which is the $\left[{ }^{3} \mathrm{H}\right]$ thymidine uptake in the presence of antigen divided by the $\left[{ }^{3} \mathrm{H}\right]$ thymidine uptake of the cells alone. 
Denmark), or with anti-CD8 $\alpha \beta$ (H57) followed by FITC-goat antimouse $\mathrm{IgG}$, and then washed. They were then analyzed by flow cytometry, using a FACScan ${ }^{\circledR}$ with Cell Quest software (Becton Dickinson, Cowley, United Kingdom).

To block $\mathrm{T}$ cell recognition and for immunohistology, we also used monomorphic anti-HLA-DR (L243), anti-DQ(L2) and anti-DP (B7-21) mAbs (25), the polymorphic anti-DR3/DR52a mAb 16.23 (26), and mAbs to TcR V $\beta 2$ (27) and V $35.2 / 5.3$ (28). Frozen sections $(6 \mu \mathrm{m})$ were stained by a two-step indirect peroxidase method with a combination of $3-3^{\prime}$ diaminobenzidine tetrahydrochloride (Sigma Chemical Co., Ltd.) and nickel chloride as chromogen (29). For double staining, the same method was used to label for CD68 (Y182; DAKO A/S) or for class II isotypes. The sections were then stained with anti-V $\beta$ mAbs and 3-amino-9-ethylcarbazole (DAKO A/S) as chromogen. Each $\mathrm{mAb}$ was applied for $30 \mathrm{~min}$, followed by washing and 15 min incubation with chromogen.

TCR gene usage. RNA was extracted from $5 \times 10^{6} \mathrm{~T}$ cells (Cinna/ Biotecx Laboratories, Witney, United Kingdom). The first strand

A

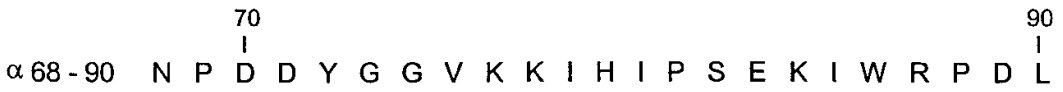

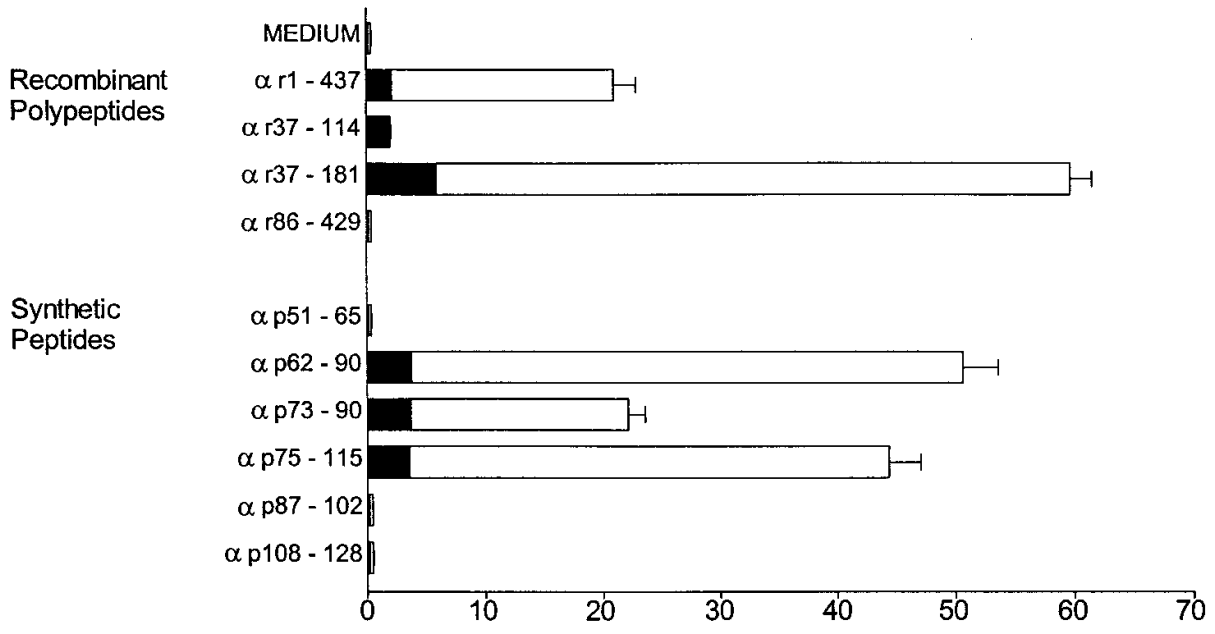

${ }^{3} \mathrm{H}$ Thymidine incorporation $\times 10^{-3}(\mathrm{cpm})$

B

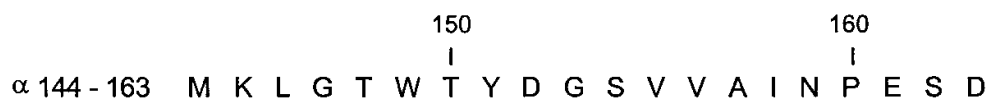

Recombinant Polypeptides

Synthetic Peptides

$\alpha 144-163 \quad M \quad K L G$ T W T Y D G S V V A I N P E S D

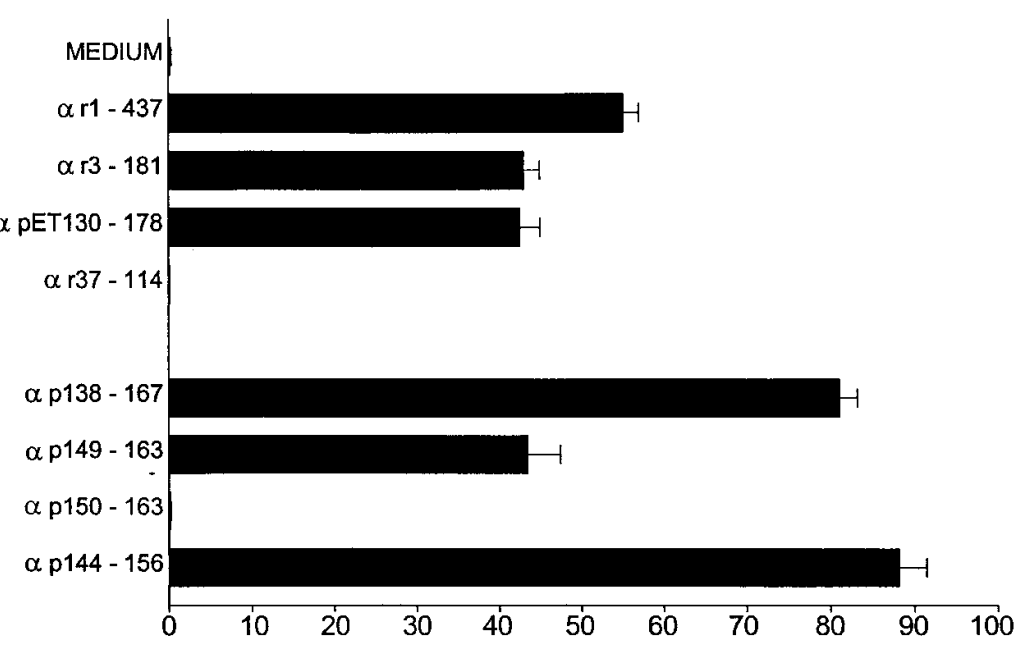

${ }^{3} \mathrm{H}$ Thymidine incorporation $\times 10^{-3}(\mathrm{cpm})$
Figure 1. (A) Epitope mapping of $\mathrm{T}$ cell line (solid bars) and clone TA-1 (open bars) from thymoma TA. T cells were cocultured with autologous PBLx plus recombinant $(r)$ or peptide $(p)$ AChR $\alpha$ subunit antigens; the former were used at 0.5 $\mu \mathrm{g} / \mathrm{ml}$, the stimulatory peptides at $1 \mu \mathrm{g} / \mathrm{ml}$, and the others at $10 \mu \mathrm{g} / \mathrm{ml}$. The human AChR $\alpha 68-90$ sequence is shown above. The line was tested after 3 mo maintenance, and gave no detectable PPD response (not shown). (B) Epitope mapping of thymoma-derived $\mathrm{T}$ cell clone TB-2. Responses to recombinant ( $r$ or $p E T)$ polypeptides $(1 \mu \mathrm{g} / \mathrm{ml})$ and synthetic peptides $(5 \mu \mathrm{M})$ are shown as in $(A)$. The human $\alpha 144$ 163 sequence is shown above. Neither clone responded to Torpedo AChR or its recombinant $\alpha$ subunit $(25,32)$. In each case, the human sequence includes known motifs for HLA-DP or DR52a (32). 
cDNA was tailed with an oligo $(\mathrm{dG})$ homopolymer; $5 \%$ of the product was used as template in the anchored PCR reaction (30). The PCR products were excised, purified, and cloned into a modified M13mp-18 vector. Up to 25 clones from each amplification were then sequenced from the $3^{\prime}$ end of the $\mathrm{J}$ region (for at least 180 bases), to identify the $\mathrm{V}$ and $\mathrm{J}$ gene segments.

\section{Results}

Characterizing $T$ cell lines and clones. T cell lines were grown from thymoma lymphocytes of $18 \mathrm{MG}$ patients by stimulation with full-length recombinant $\mathrm{AChR} \alpha$ subunit using autologous PBLx as APC, and clones were subsequently grown from nine of them. With one strong responder (TA) and one modest responder (TB), both with a recent onset of MG (Table I), we were successful in mapping epitopes with synthetic peptides (see below), perhaps because of higher precursor frequencies or a greater sensitivity to the low concentrations of antigen available. Even in these cases, there was a tenfold excess of irrelevant clones (e.g., reacting to the IL-2 by itself or to E. coli polypeptides, despite careful antigen purification; reference 25) as were obtained exclusively from the other seven thymomas.

Epitope mapping. Both the TA and TB lines and clones proved to be specific for epitopes from the extracellular $(\alpha 1-$ 210) domain (Fig. 1, $A$ and $B$ ). The slow-growing line from thymoma TA showed a consistent response to $\mathrm{r} 37-181$ that was gradually enriched while that to PPD disappeared. Using recombinant polypeptides, we mapped the epitope near to position 86 for both this line and its TA- 1 clone (Fig. $1 A$ ). Recognition of three independent overlapping synthetic peptides, p62-90, p73-90, and p75-115, but not of the adjacent peptides tested (Fig. $1 A$ ), defined the epitope core as residues $\alpha 75-90$.

One line initiated from thymoma TB against $\mathrm{r} 3-181$ responded significantly and was cloned after $2 \mathrm{wk}$. Two clones (TB-2 and TB-3) proved to be specific for the $\alpha 130-178$ region; their maximal responses mapped the epitope core to the $\alpha 149-158$ region for both (Fig. $1 \mathrm{~B}$ ). Clone TB-2 was characterized in detail.

Responses to human AChR. AChR-specific T cell clones consistently respond well to minute amounts of whole AChR extracted from human muscle and captured onto immunomag-
Table II. HLA-DP Restriction of Clone TA-1

\begin{tabular}{|c|c|c|c|c|c|c|c|}
\hline \multirow{3}{*}{$\begin{array}{l}\text { Presenting } \\
\text { B cell line }\end{array}$} & \multirow{3}{*}{$\begin{array}{l}\text { Percent of maxi- } \\
\text { mum response }\end{array}$} & \multicolumn{3}{|c|}{ HLA-DP $\alpha$} & & \multicolumn{2}{|c|}{ HLA-DP $\beta$} \\
\hline & & \multirow[t]{2}{*}{ Allele } & \multicolumn{3}{|c|}{ Sequence } & \multirow[t]{2}{*}{ Allele } & \multirow{2}{*}{$\begin{array}{c}\text { Sequence } \\
9\end{array}$} \\
\hline & & & 23 & 50 & 83 & & \\
\hline \multirow[t]{2}{*}{ Autologous } & $100 \pm 1.7$ & 0201 & Gln & Arg & Ala & 1401 & His \\
\hline & & 01 & Met & Gln & Thr & 0401 & Phe \\
\hline \multirow[t]{2}{*}{ Mother } & $94 \pm 6.6$ & 0201 & Gln & Arg & Ala & 1401 & His \\
\hline & & 0201 & & & & 0901 & His \\
\hline \multirow[t]{2}{*}{ Father } & $0.9 \pm 0.05$ & 01 & Met & Gln & Thr & 0301 & Tyr \\
\hline & & 01 & & & & 0401 & Phe \\
\hline \multirow[t]{2}{*}{ KAS011 } & $70 \pm 8.9$ & 0201 & Gln & Arg & Ala & 1401 & His \\
\hline & & 01 & Met & Gln & Thr & 0401 & Phe \\
\hline
\end{tabular}

The indicated B cell lines were prepulsed with p73-90 (at $5 \mu \mathrm{g} / \mathrm{ml}$ ) for $3 \mathrm{~h}$ before washing and coculturing with Clone TA-1. Shown at the right are the HLA-DP $\alpha / \beta$ allele combinations; also shown are the only sequence differences between the 0201/1401 combination that presents antigens to this clone and the very similar paternal $01 / 0301$ that does not. DP $\beta$ 0401 also differs at 12 other positions in addition to those shown here.

netic beads by specific mAbs $(22,24)$. In two experiments, responses of TA-1 to beads-mAb-AChR reached $26-58 \%$ of the maximum seen with r37-181 (Fig. $2 A$ ). The TB-2 clone also showed consistent and specific responses to similar amounts of AChR (Fig. 2 B). Recently, with more concentrated AChR from the $\epsilon$ subunit-transfected TE671 cells (31), stimulations have regularly reached $60 \%$ of the maximum (not shown).

The restricting $\mathrm{MHC}$ elements. Both clones proved to use minority presenting class II molecules. Initially, their responses (with autologous PBLx) were blocked almost impartially by monomorphic mAbs to HLA-DR, DQ, and DP (not shown). However, we saw a clear discrimination when we used autologous B cell lines (prepulsed with peptides); with clone TA-1, only the anti-DP mAb blocked (by 96\%). We then established that this clone required the rare (maternal) DPB*1401 plus DPA*0201, which are shared by the B cell line KAS011 (Table II). The father's APC gave completely nega-
A

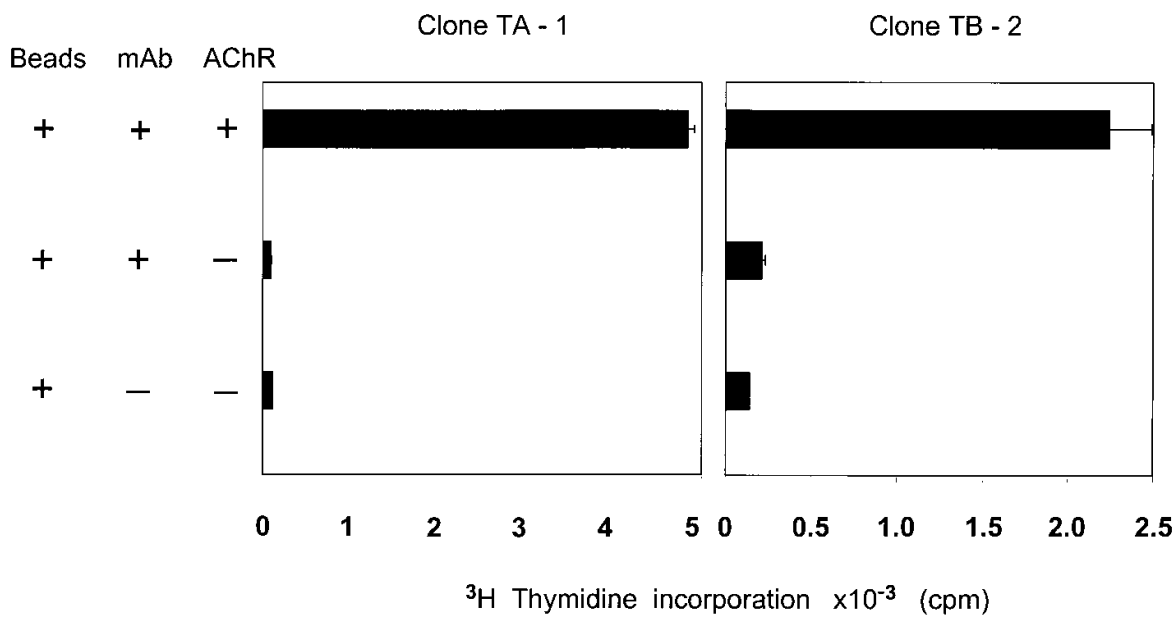

Figure 2. Responses of thymoma-derived clones TA-1 $(A)$ and TB-2 $(B)$ to human AChR. Muscle AChR was incubated with Dynabeads 450 precoated (or not) with mAb B3 (specific for human AChR) before culturing with $\mathrm{T}$ cells plus autologous PBLx (22). 


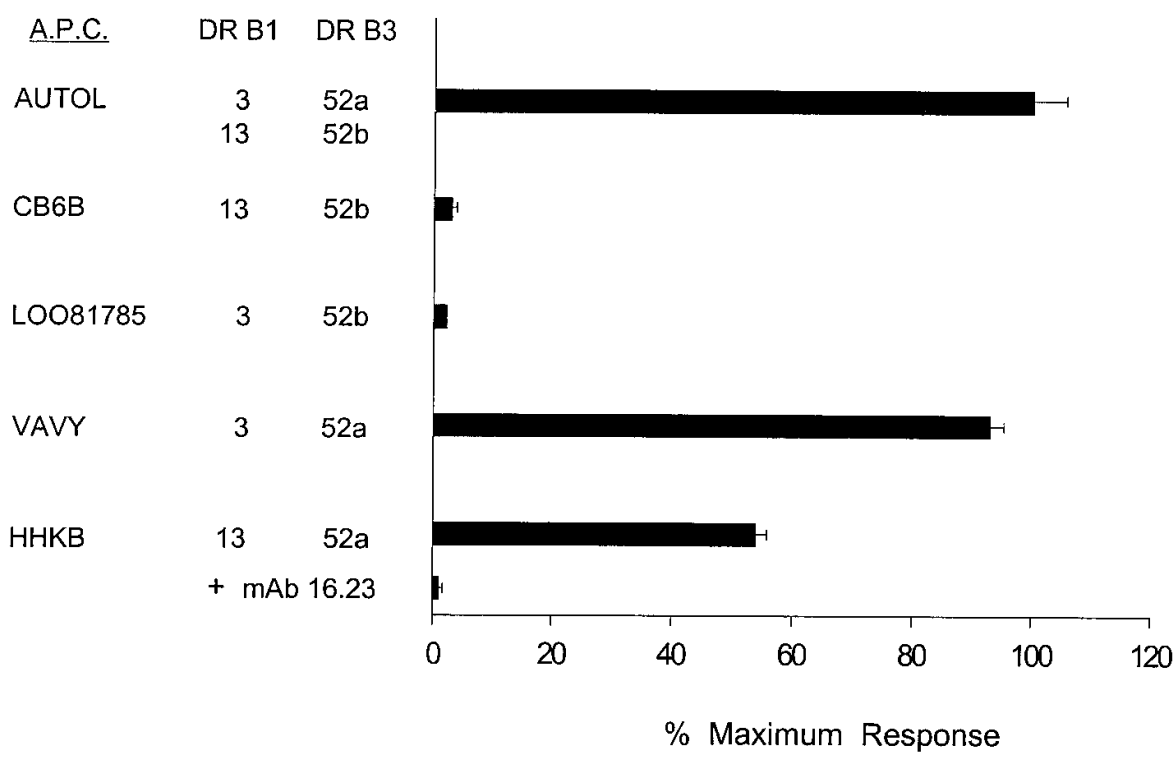

Figure 3. HLA-restriction of thymomaderived clone TB-2. Autologous and other B cell lines were pre-pulsed with p144-163 $(10 \mu \mathrm{g} / \mathrm{ml})$ before coculture with the T cells. mAb $16.23(m A b)$, which is specific for DR3 and DR52a, blocked this response with HHKB B cells. The shared HLA-DR alleles are: DR3, DRB1*0301; DR13, $D R B 1 * 1301$; DR52a, $D R B 3 * 0101$; and DR52b, $D R B 3 * 0202$. tive results, even though his DPB $1 * 0301$ differs only at one position and his DPA $1 * 01$ only at three (Table II).

For the TB-2 clone, use of a panel of B cell lines pre-pulsed with p144-163 identified HLA-DR52a as the restricting element (Fig. 3). The donor is heterozygous for HLA-DR3/ DR52a and DR13/DR52b. Lines that shared only DR13/ DR52b or DR3/DR52b failed to present this peptide, whereas those with DR52a gave maximal stimulation regardless of whether they were $\mathrm{DR}^{+}$. Moreover, responses were clearly blocked by the polymorphic mAb 16.23 that is specific for DR52a and DR3 (reference 26, Fig. 3).

Surface markers. Surprisingly, both clones showed moderate labeling for $\mathrm{CD} 8 \alpha$ in addition to the expected strong CD4 expression (Fig. $4 a$ ), although they did not stain with mAbs specific for $\mathrm{CD} 8 \alpha \beta$ (Fig. $4 \mathrm{~b}$ ) or $\mathrm{CD} 8 \beta$ (not shown). In the original line from patient TA, $\sim 20 \%$ of the cells were CD $4^{+}$ with low $\mathrm{CD} 8 \alpha$. No double positivity was seen in another AChR-specific clone, PM-Al raised from hyperplastic MG thymus (Fig. 4), or in four from PBL of MG patients without a thymoma, all of which have a Th1 phenotype (32).

$T C R$ gene usage. We found a single potentially functional TCR $\alpha \beta$ chain combination in each clone (Table III). Notably, whereas their $\mathrm{V} \beta$ sequences were different, they used the same $A V 1 S 2$ and $J 17 S 2$ germline gene segments; the intervening junctional regions were both short, and differed at only three amino acid positions (Table III). We also found that a $\mathrm{mAb}$ to $\mathrm{V} \beta 2$ blocked responses of clone TB-2 to appropriate peptide or recombinant antigens by 93 and $99 \%$, respectively. There was no inhibition with an anti-V $\beta 13.1 \mathrm{mAb}$ (not shown).

Cytokine profiles. The cytokine profiles of both clones showed a Th0 pattern when assayed serially for IFN- $\gamma$ and IL-4 secretion after antigen stimulation with PBLx as APC (Fig. 5). There was clear production of both cytokines that correlated well with the proliferative responses, but reached maximum by 16-24 rather than 48-72 h, especially for IL-4 (Fig. 5).

In keeping with this Th0 behavior, the addition of IL-4 (25 $\mathrm{ng} / \mathrm{ml}$ ) on day 0 of the growth cycle enhanced both the expansion of clone TA-1 by two- to fivefold and its subsequent responsiveness to antigens (including purified AChR) by threeto fourfold. These trends were similar but weaker with clone TB-2 (not shown).

The APC activity of thymoma epithelial cells. To explore the autosensitizing potential of the neoplastic epithelial cells, these were cultured from thymoma TB in parallel with fibro-
TA-1

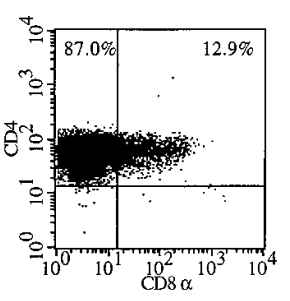

b

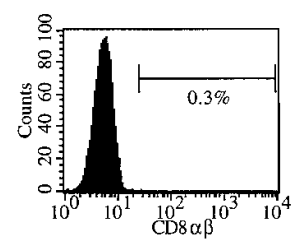

TB-2
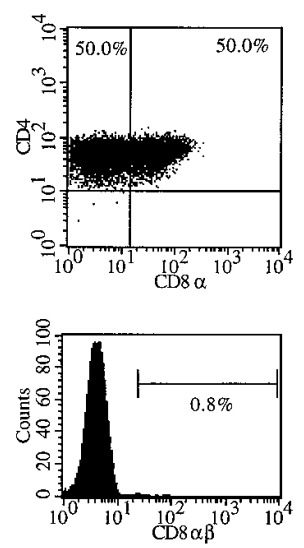

H-1
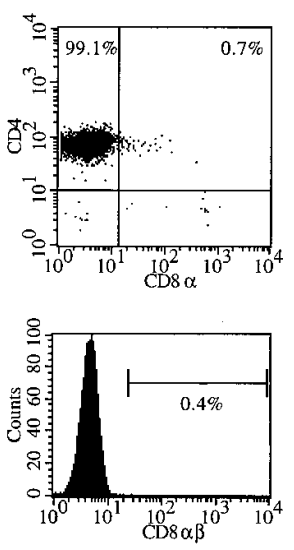

PBMC
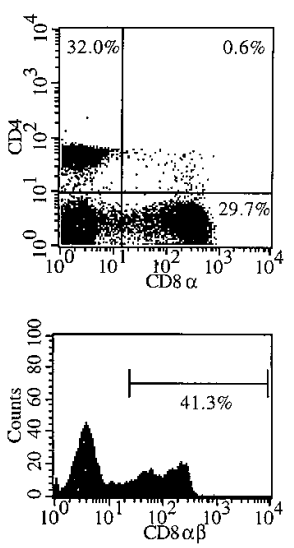

Figure 4. Flow cytometric analysis of T cell clones. TA-1, TB-2, H1 (clone PM-A1 from a hyperplastic MG thymus [25]) and PBMC (from a healthy donor) were stained for the expression of $(a) \mathrm{CD} 4$ and $\mathrm{CD} 8 \alpha$ or $(b) \mathrm{CD} 8 \alpha \beta$. 
Table III. TCR Junctional Region Sequences of Clones TA-1 and TB-2

\begin{tabular}{|c|c|c|c|}
\hline Clone & & $\mathrm{V}$ & \\
\hline & $\mathrm{TCR} \alpha$ & & \\
\hline \multirow[t]{2}{*}{ TA-1 } & AV1S2 & $\begin{array}{llllllllll}G & Y & Q & K & V & T & F\end{array}$ & J17S2 \\
\hline & & gggttaccagaagttaccttt & \\
\hline \multirow[t]{3}{*}{ TB-2 } & AV1S2 & $\begin{array}{llllllllllllll}C & A & V & S & G & S & G & G & Y & Q & K & V & T & F\end{array}$ & \\
\hline & & tgtgctgtgagtg gg tctgggggttaccagaaagttaccttt & $\mathrm{J} 17 \mathrm{~S} 2$ \\
\hline & TCR $\beta$ & & \\
\hline \multirow[t]{2}{*}{ TA-1 } & BV20S1 & $\begin{array}{llllll}R & \mathrm{~T} & \mathrm{G} & \mathrm{L} & \mathrm{S} & \mathrm{G}\end{array}$ & J1S4 \\
\hline & & gcctggagtgt acgaacaggcctcagcgg aaactgttt & \\
\hline \multirow[t]{2}{*}{ TB-2 } & BV2S1 & 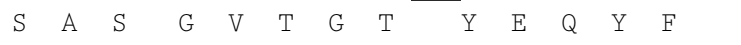 & $\mathrm{J} 2 \mathrm{~S} 7$ \\
\hline & & agtgctag cggagtgacaggaa cctacgagcagtacttc & \\
\hline
\end{tabular}

Nucleotide and predicted amino acid sequence of the CDR3 region of TCRA and TCRB transcripts from clones TA-1 and TB-2. TCRA sequences are shown between the conserved cysteine at the $3^{\prime}$ end of the TCRAV transcript and the conserved phenylalanine residue in TCRAJ sequences. Germline TCRAJ and probable germline TCRAV sequences are separated from nucleotides added by $\mathrm{N}$ region addition, as also for TCRB. TCRB sequences are shown after the conserved cysteine at the $3^{\prime}$ end of TCRBV and including the conserved phenylalanine in TCRBJ. Germline TCRBV and $T C R B J$ sequence is separated from the rest of the CDR3 sequence. Probable contributions from TCRBD segments are underlined. Because of the striking similarity in TCRAV sequences, we tested whether clone TB-2 could recognize p144-163 or p75-115 presented by the DPB1*1401+ B cell line of patient TA, but the results were negative (not shown).

blasts from the tumor capsule. When pretreated with IFN- $\gamma$ (to induce class II expression), the epithelial cells presented added antigens much better to the autologous clone TB-2 than did his fibroblasts (Fig. 6). Moreover, they were capable of processing long polypeptides (r3-181, Fig. $6 A$ ). Notably, the epithelial cells also evoked greater production of both IL-4 and IFN- $\gamma$ than did PBLx (Fig. 6, $A$ and $B$ ), whereas the proliferative responses were stronger with PBLx (Fig. $6 C$ ). However, there was no detectable response in the absence of added antigen.

Autosensitizing cell types in the donor thymomas. We finally scrutinized the donor tumors for potential sites of autosensitization by immunolabeling for the presenting class II molecules and also, in TB, for the V 32 used by his TB- 2 clone. The HLA-DP isotype is expressed weakly by peripheral APC $(33,34)$ and lymphoid tissues, but more strongly in the thymus (35). Tumor TA was a typical cortical thymoma. All three class II isotypes were expressed strongly on the numerous scattered $\mathrm{CD} 8^{+}$macrophages and in the occasional medullary areas, but HLA-DP and DQ were more variable on the cortical epithelial cells (as in other MG thymomas, not shown). There were also rare class $\mathrm{II}^{+} \mathrm{B}$ cell foci in the perivascular spaces (PVS; not shown). Thus, there appeared to be frequent opportunities for T cells to encounter HLA-DP molecules on both epithelial cells and professional APC.

In contrast, professional APC were the most conspicuous class II-expressing cells in thymoma TB. As expected after corticosteroid pretreatment (8), this tumor contained very few $\mathrm{CD}^{+}{ }^{+}$thymocytes, and consisted largely of epithelial cells, but these expressed class II antigens more weakly than in other pretreated cases. The $\mathrm{CD}^{+} \mathrm{T}$ cells were also sparse in the tumor parenchyma, and were more concentrated in the PVS. The numerous $\mathrm{CD} 68^{+}$macrophages were strongly class $\mathrm{II}^{+}-$ expressing DR52a/DR3 - in both sites. They appeared to be preferentially contacted by $\mathrm{V} \beta 2^{+} \mathrm{T}$ cells in particular (Fig. 7 $A$ ), rather than $\mathrm{V} \beta 5.2^{+}$cells (Fig. $7 \mathrm{~B}$ ), as did the rare foci of $\mathrm{CD} 19^{+} \mathrm{B}$ cells observed in the larger PVS (Fig. 7, $C$ and $D$ ); however, we saw no selective V $\beta 2$ expansion in any site. We had no other thymomas matched for HLA and steroid pretreatment for further comparisons.

\section{Discussion}

We have cloned and characterized, for the first time, AChRspecific $\mathrm{T}$ cells from MG thymomas by stimulation with recombinant human AChR $\alpha$ subunit. Both clones recognize epitopes from the extracellular domain of the receptor that can be processed very efficiently from the whole molecule. They are highly specific for the human (rather than electric fish) sequences, and for the correct class II alleles that present them. These both proved to be minority isotypes that were expressed more strongly on professional APC in the donor thymoma than on the neoplastic epithelium. Both clones have a $\mathrm{CD}^{+}$ $\mathrm{CD} 8 \alpha^{+}$surface phenotype, a Th0 cytokine profile, and use TCRs with very similar $\mathrm{V} \alpha-\mathrm{J} \alpha$ sequences; these characteristics distinguish them from the clones we isolated similarly from other MG patients without tumors (32), and suggest that specific $\mathrm{T}$ cells are generated and actively sensitized in MG thymomas where they acquire a helper phenotype. Therefore they favor the hypothesis of active T cell selection/sensitization in thymomas, and argue against that of a simple failure to tolerize developing thymocytes.

Although both $\mathrm{T}$ cells were selected against the whole AChR $\alpha$ subunit, their epitopes, $\alpha 75-90$ and $\alpha 149-158$, derive from the extracellular domain of the native protein that is also recognized by the patients' B cells and serum anti-AChR antibodies $(12,36,37)$. The intact conformation of this domain has never been detected in thymomas (13). However, since the expression of mRNAs encoding both the AChR $\alpha$ subunit (1416) and especially the $\epsilon$ subunit (MacLennan, C., D. Beeson, N. Willcox, A. Vincent, and J. Newsom-Davis, manuscript in preparation) might lead to the production of small amounts of AChR subunit polypeptides in thymomas, it will be important to investigate both their cellular distribution in the tumors and whether it correlates with specific $\mathrm{T}$ cell responses to them. Whereas previous studies have shown expression of an AChR- 
Clone TA - 1
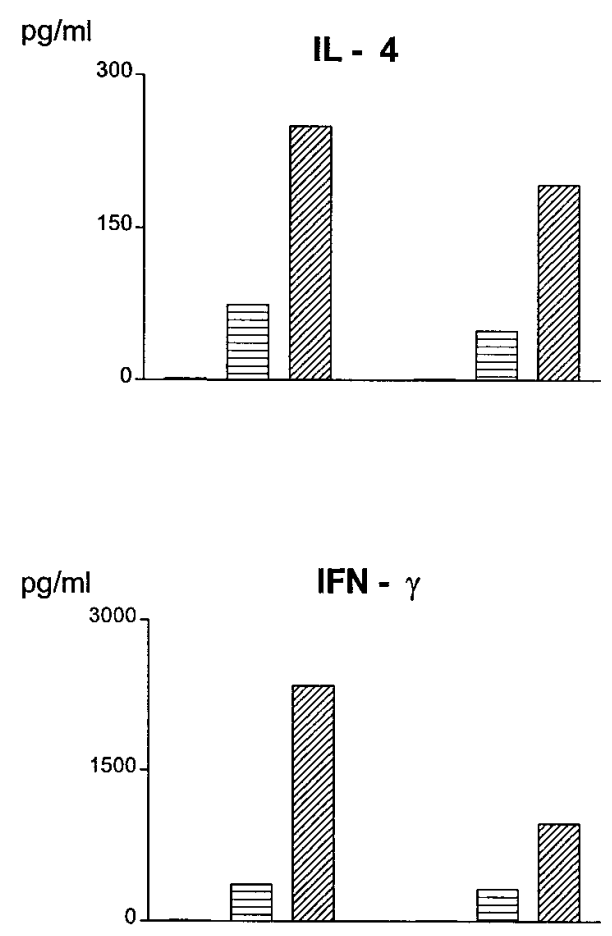

${ }^{3} \mathrm{H}$ Thymidine incorporation

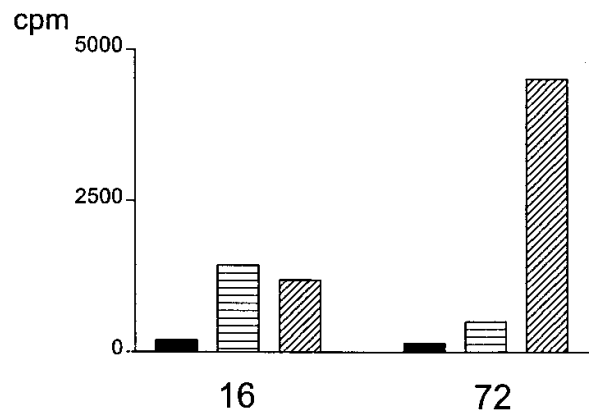

TIME (h)
Clone TB - 2

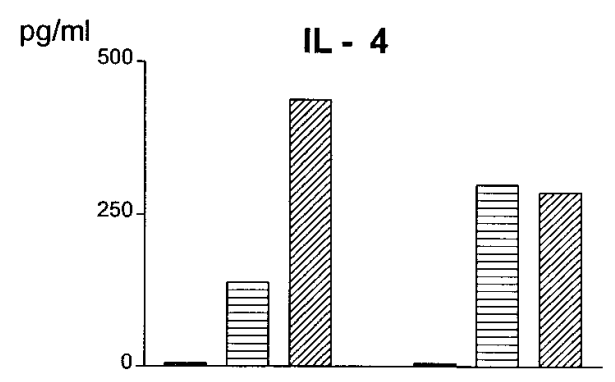

$\mathrm{pg} / \mathrm{ml}$

IFN $-\gamma$

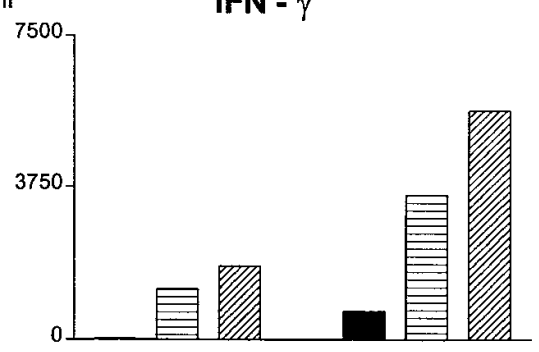

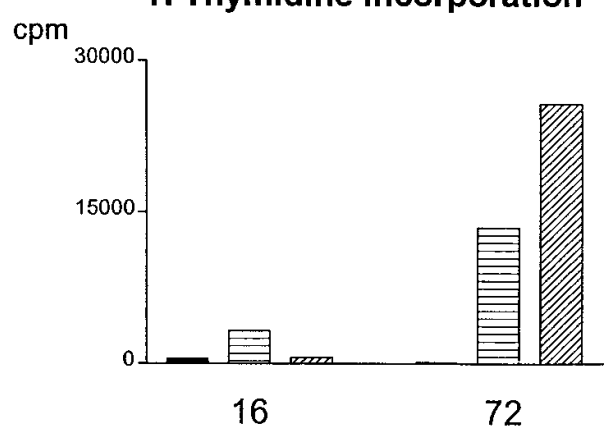

Figure 5. Production of IL-4 and IFN- $\gamma$ by thymoma-derived clones. Well-washed $\mathrm{T}$ cells were cultured with PBLx plus medium alone (solid bars), r1-437 (horizontally striated bars), or peptides $75-115$ for clone TA-1 or 144-163 for TB-2 (hatched bars). At the time shown, supernatants were sampled for cytokine assays (by ELISA), and ${ }^{3} \mathrm{H}$ thymidine was added, followed by harvesting and $\beta$ counting $18 \mathrm{~h}$ later.

like epitope resembling the cytoplasmic sequence $\alpha 371-380$ in MG thymomas (13), we have found no evidence of either T cell or antibody responses to the entire cytoplasmic domain in thymoma/MG patients (38). Indeed, this epitope is now believed to be on a neurofilament chain rather than any AChR subunit $(17,18)$.

Remarkably, both clones use the same TCRAV and $T C R A J$ gene segments. That is unlikely to have occurred by chance, since over 50 functional TCRAV gene segments and over $60 T C R A J$ gene segments are available. Their preferential pairing is a possibility, but has not been seen in over 500 $T C R A V J$ sequences analyzed to date $(30,39$; our unpublished observations) or in the GenEMBL database. However, preferential selection of certain TCRAV/AJ combinations might be more likely in the T cells developing in this abnormal environment. Interestingly, both $T C R A V / A J$ transcripts have very few $\mathrm{N}$ region nucleotides at the $\mathrm{V}-\mathrm{J}$ junction, whereas, in the $T C R B V J$ segments (which rearrange before the TCRAVJ), these $\mathrm{N}$ regions appear normal in length (Table III). There are known to be abnormalities in the development, especially of $\mathrm{CD}^{+}$thymocytes, in MG thymomas (40). Concomitant changes, such as an accelerated maturation, could differentially affect $T C R A V$ rearrangement.

By contrast, the presence of CD $8 \alpha$ on both clones probably 

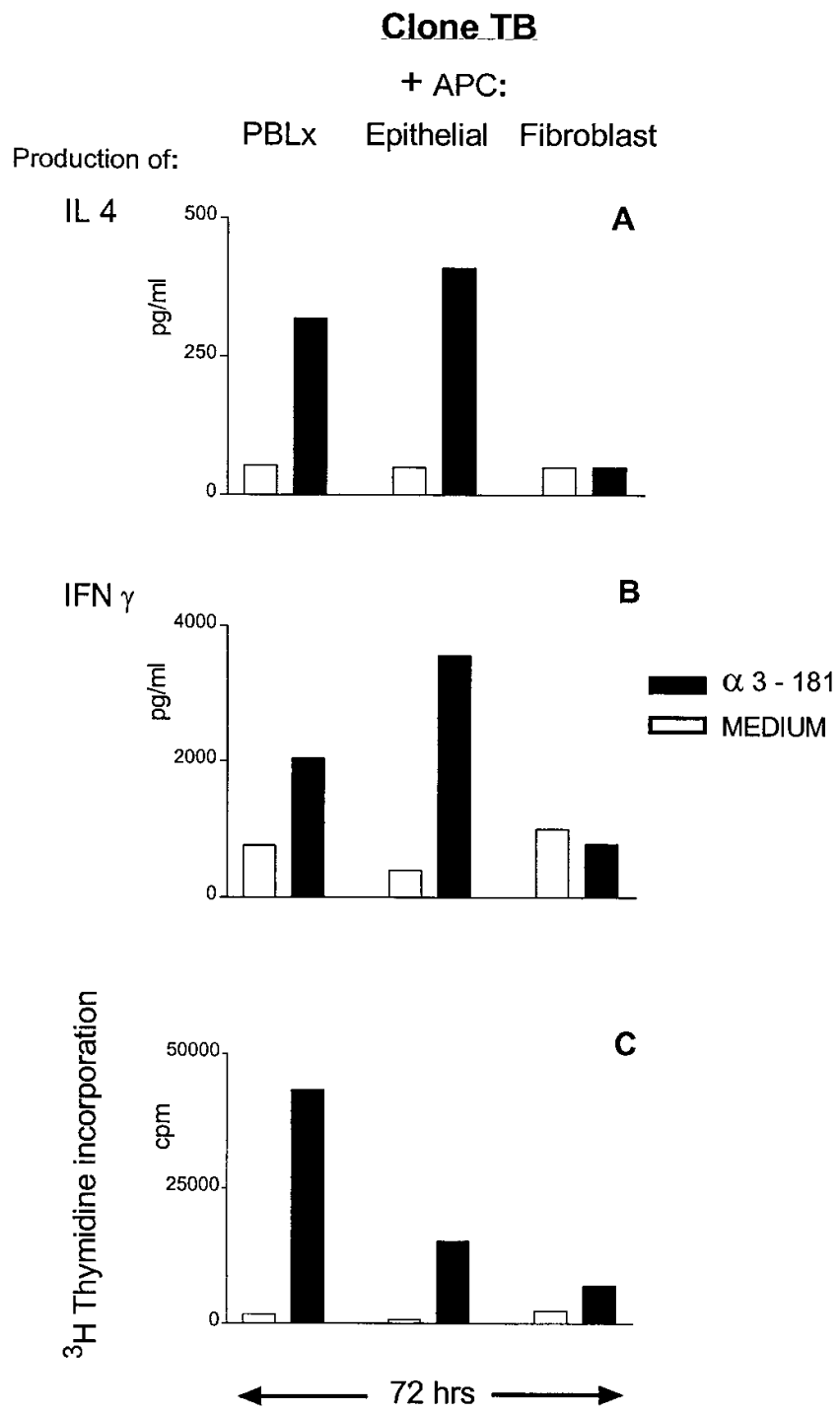

Figure 6. Presentation of $\alpha 3-181$ to clone TB-2 by PBLx and autologous thymoma epithelial cells and fibroblasts. The TB-2 T cells were cocultured with $>95 \%$ pure epithelial cells or fibroblasts (both pretreated with IFN- $\gamma$ ), or with PBLx for $72 \mathrm{~h}$ with or without $\alpha 3-181$ $(1 \mu \mathrm{g} / \mathrm{ml})$. Parallel responses to peptide $144-163(20 \mu \mathrm{g} / \mathrm{ml})$ were approximately two times greater, and the epithelial cells evoked threefold higher IL-4 and fivefold higher IFN- $\gamma$ than did PBLx (not shown).

correlates with their capacity to secrete IL-4 (41). While it might, in theory, help the same TCRs additionally to recognize peptide(s) presented by class I molecules, they in fact showed strong CD4 positivity and typical class II-restricted behavior. Indeed, clone TB-2 responded well to DR52a-transfected mouse fibroblasts, which express no human class I molecules (Nagvekar, N., L. Corlett, L.W. Jacobson, H. Matsuo, P. Driscoll, S. Desphande, E.G. Spack, A. Vincent, and N. Willcox, manuscript in preparation).

Unexpectedly, both of these $\mathrm{T}$ cells proved to use minority class II restricting elements. HLA-DP is expressed about 50 times more weakly on peripheral APC than HLA-DRB1 molecules $(33,34)$. For DR52a, the difference is less certain, but is thought to be about three- to fivefold (42). In theory, this weak expression might render these molecules (and their resident peptides) less likely to induce tolerance in developing thymocytes. However, both were expressed so strongly by the professional APC in the donor tumors that active sensitization seems likelier. This preference for minority restricting elements might help to explain why no clear associations with any HLA alleles have been reported in MG patients with thymoma, in contrast with other MG subgroups. Associations with minority isotypes, especially at or near HLA-DP, could easily have been overlooked, particularly if they are as allelespecific as the DP-restriction of clone TA-1 (Table II).

Thymoma epithelial cells evidently have significant antigen-presenting potential (Fig. 6), though other evidence suggests that the professional APC may be the likelier autosensitizing cell type (see below). The epithelial cells were clearly HLA-DP $^{+}$in thymoma TA, and might have been more strongly class $\mathrm{II}^{+}$before the corticosteroid pretreatment in TB. Moreover, when cultured from the latter, and pre-treated with IFN- $\gamma$ (43), they not only presented peptides very well, but also processed longer antigens effectively, evoking even greater cytokine production than PBLx by the autologous clone TB-2. However, this T cell showed no detectable recognition of endogenously processed epitope in these epithelial cells; to compare these cells with the professional APC in the same thymoma would be a critical experiment. Ideally, one would use an even more sensitive T cell such as PM-A1 $(22,25)$, though its restricting HLA-DR allele is rare.

The key features common to all of these histologically variable tumors in MG may be the presence of developing thymocytes and the potent presenting activity for muscle autoantigens (44). Several arguments incriminate the professional APC as agents provocateurs. They were more consistently class II positive than the epithelial cells, especially in thymoma $\mathrm{TB}$, where they made particularly close contacts with $\mathrm{T}$ cells expressing the same V 32 as his clone TB-2. Furthermore, in chimeric laboratory rodents, these APC can mediate unnatural positive selection, and generate an abnormally broad repertoire of autoreactive $\mathrm{T}$ cells (45). They may be further implicated by our recent finding of high neutralizing antibody titers in MG/thymoma patients against IFN- $\alpha$ and IL-12 (46). Both of these are mainly produced by professional APC, which could be immunizing not only against muscle antigens but also against the cytokines themselves.

Because both IFN- $\alpha$ and IL-12 normally bias towards Th1 responses, their neutralization may help to explain the Th0 behavior of our two specific clones. It contrasts sharply with the clearly Th1 phenotype of the six $\mathrm{T}$ cells we have cloned from other MG patients without thymomas, which are all $\mathrm{CD} 4^{+}$ $\mathrm{CD}^{-}$, and are unequivocally Th1 (producing no detectable IL-4; reference 32). Only one of these (PM-A) was derived from a hyperplastic MG thymus (despite multiple attempts); it recognizes exactly the same peptides as TB-2, but uses V $\beta 5.1$ and HLA-DR4 to do so $(24,25)$. The remainder originate from PBL, and four of them respond to a recurring $\epsilon$ 201-219 epitope presented by DR52a (32). Thus, the thymoma-derived clones appear distinctive in both their CD8 $\alpha$ expression and Th0 phenotype, as well as their $\mathrm{V} \alpha$ usage. However, it is still premature to say whether the autosensitization process is different in thymic hyperplasia.

Several other lines of evidence point to the potential pathogenicity of our thymoma-derived T cell clones. The $\alpha 149-158$ region recognized by clone $\mathrm{TB}-2$ is an important pathogenic 


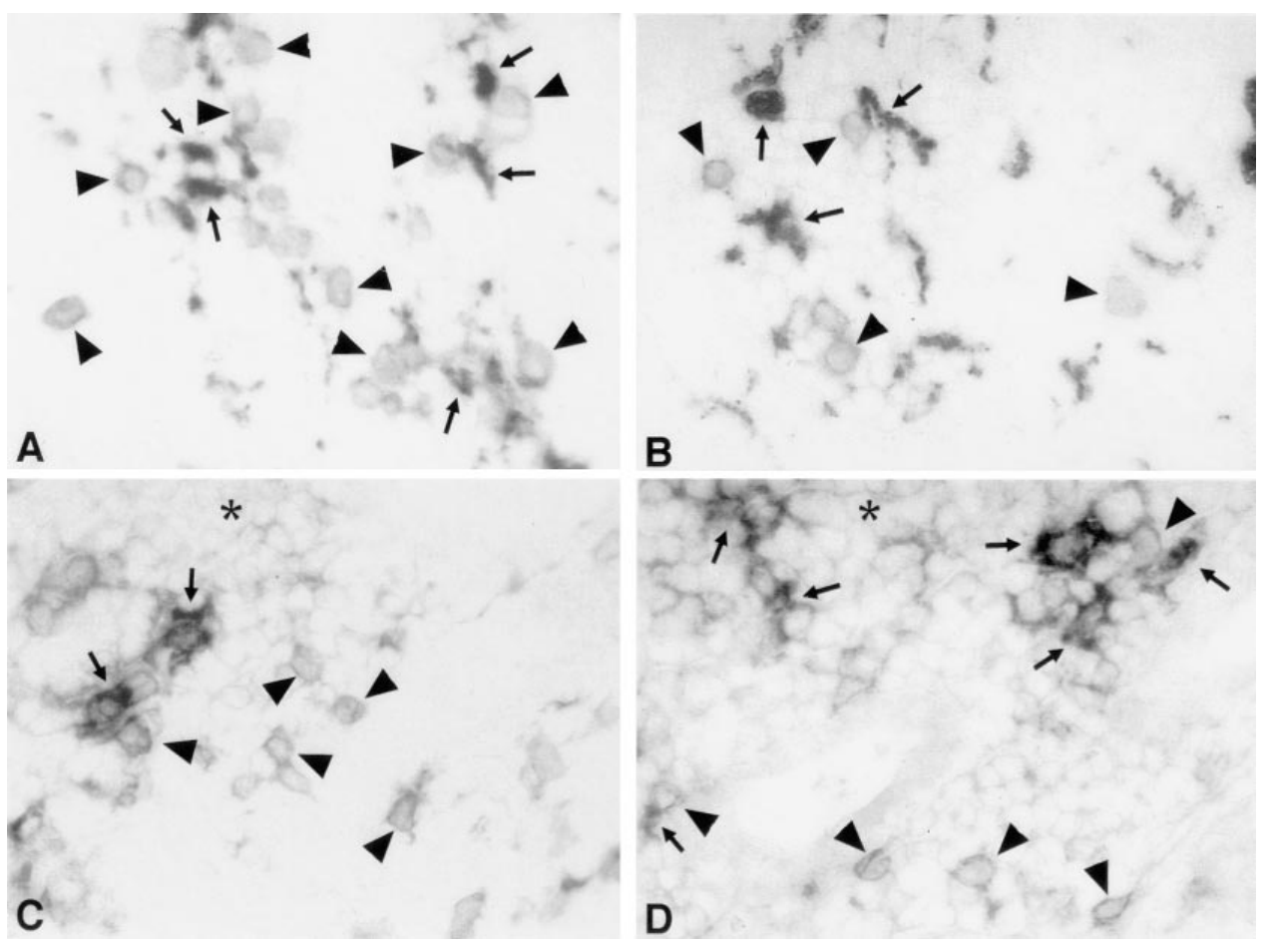

Figure 7. Sections of thymoma TB double-stained for TCR V $\beta$ (arrowheads) and either CD68 (for macrophages; $A$ and $B$ ) or mAb 16.23 (for DR3/DR52a; $C$ and $D$; arrows). In the tumor parenchyma ( $A$ and $B), \mathrm{V} \beta 2^{+} \mathrm{T}$ cells apparently contact $\mathrm{CD}^{+} 8^{+}$macrophages $(A)$ more frequently than do V $\beta 5.2 / 5.3^{+} \mathrm{T}$ cells $(B)$. In a rare perivascular focus of B cells (class $\mathrm{II}^{+} ; C$ and $D$; arrows), there are several contacts with $\mathrm{V} \beta 2^{+}$ $\mathrm{T}$ cells $(C)$, whereas $\mathrm{V} \beta 5.2 / 5.3^{+}$ T cells are less frequent $(D)$. This donor had been pretreated with daily corticosteroids for $4 \mathrm{wk}$. epitope in laboratory mice (47). Perhaps because of its very efficient processing from whole AChR (Fig. 2), it is also a recurring natural epitope for human $\mathrm{T}$ cells, including PM-A. The TA- 1 clone is also very sensitive to whole AChR. Its epitope is close to the $\alpha 67-76$ sequence which contributes to the main immunogenic region (MIR; references 36 and 48) that many MG patients' autoantibodies recognize. Thus, $T$ cells such as TA-1 and TB-2 would probably be efficient helpers for MIRspecific B cells. In this context, it is interesting that we found occasional perivascular B cell foci in both thymomas. These have been noted previously, and so has sporadic anti-AChR antibody production in culture (reference 49, as seen with thymoma TA, not shown). The infiltration of these foci by $\mathrm{VB2}^{+} \mathrm{T}$ cells is intriguing, though it might merely reflect a general preference of $\mathrm{V} \beta 2^{+}$TCR for HLA class II rather than class I (27).

In conclusion, both the autoepitopes expressed in MG thymomas and the responding $\mathrm{T}$ cells are providing important etiological clues. Our findings already argue strongly in favor of biased selection/active sensitization by professional APC in thymomas, rather than a mere failure to tolerize developing $\mathrm{T}$ cells. Moreover, if these epitopes and/or pathogenic $\mathrm{T}$ cells show a restricted heterogeneity, that might suggest approaches for selective immunotherapy for which promising strategies now exist $(50,51)$, and for which there is often a particular need in thymoma patients with MG.

\section{Acknowledgments}

We thank Professors G. Janossy and A.W. Boylston for mAbs and Dr. D. Miller for access to patient TB. We are also extremely grateful for the loyal help not only of this patient but also of TA and his parents, to Dr. S.G.E. Marsh and Dr. K.J. Micklem for invaluable advice, and to Gareth Plant for supplying B cell lines.
This work was supported by the Sir Jules Thorn Charitable Trust, the Medical Research Council, the Myasthenia Gravis Association/ Muscular Dystrophy Group, and by a fellowship from the EC (for I.R.).

\section{References}

1. Souadjian, J.V., P. Enriquez, M.N. Silverstein, and J.-M. Pepin. 1974. The spectrum of diseases associated with thymoma. Arch. Intern. Med. 134:374-379.

2. Lang, B., and A. Vincent. 1996. Autoimmunity to ion-channels and other proteins in paraneoplastic disorders. Curr. Opin. Immunol. 8:865-871.

3. Marx, A., and H.K. Müller-Hermelink. Epithelial Tumors of the Thymus; Pathology, Biology, Treatment. Plenum Publishing Corp., New York. 399 pp.

4. Willcox, N. 1993. Myasthenia gravis. Curr. Opin. Immunol. 5:910-917.

5. Beeson, D., M. Brydson, M. Betty, S. Jeremiah, S. Povey, A. Vincent, and J. Newsom-Davis. 1993. Primary structure of the human muscle acetylcholine receptor: cDNA cloning of the gamma and epsilon subunits. Eur. J. Biochem. 215:229-238.

6. Williams, C.L., and V.A. Lennon. 1986. Thymic B lymphocyte clones from patients with myasthenia gravis secrete monoclonal striational antibodies reacting with myosin, alpha-actinin or actin. J. Exp. Med. 164:1043-1059.

7. Aarli, J.A., K. Stefansson, L.S.G. Marton, and R.L. Wollmann. 1990. Patients with myasthenia gravis and thymoma have in their sera IgG autoantibodies against titin. Clin. Exp. Immunol. 82:284-288.

8. Willcox, N., M. Schluep, M.A. Ritter, H.J. Schuurman, J. Newsom-Davis, and B. Christensson. 1987. Myasthenic and nonmyasthenic thymoma. An expansion of minor cortical epithelial cell subset? Am. J. Pathol. 127:447-460.

9. Chilosi, M., A. Ianucci, L. Fiore-Donati, G. Tridente, M. Pampanin, G. Pizzolo, M. Ritter, M. Bofill, and G. Janossy. 1986. Myasthenia gravis: immunohistological heterogeneity in microenvironmental organisation of hyperplastic and neoplastic thymuses suggesting different mechanisms of tolerance breakdown. J. Neuroimmunol. 11:191-204.

10. Gilhus, N.-E., J.A. Aarli, B. Christensson, and R. Matre. 1984. Rabbit antiserum to a citric acid extract of human skeletal muscle staining thymomas from myasthenia gravis patients. J. Neuroimmunol. 7:55-64.

11. Dardenne, M., W. Savino, and J.-F. Bach. 1987. Thymomatous epithelial cells and skeletal muscle share a common epitope defined by a monoclonal antibody. Am. J. Pathol. 126:194-198.

12. Tzartos, S.J., M.E. Seybold, and J.M. Lindstrom. 1982. Specificities of antibodies to acetylcholine receptors in sera from myasthenia gravis patients measured by monoclonal antibodies. Proc. Natl. Acad. Sci. USA. 79:188-192.

13. Kirchner, T., S. Tzartos, F. Hoppe, B. Schalke, H. Wekerle, and H.K. Müller-Hermelink. 1988. Pathogenesis of myasthenia gravis: acetylcholine receptor-related antigenic determinants in tumor-free thymuses and thymic epi- 
thelial tumors. Am. J. Pathol. 130:268-280.

14. Hara, Y., S. Ueno, T. Uemichi, N. Takahashi, S. Yorifujii, Y. Fujii, and S. Tarui. 1991. Neoplastic epithelial cells express $\alpha$-subunit of muscle nicotinic acetylcholine receptor in thymomas from patients with myasthenia gravis. FEBS. Lett. 279:137-140.

15. Wheatley, L.M., D. Urso, K. Tumas, J. Maltzman, E. Loh, and A.I. Levinson. 1992. Molecular evidence for the expression of nicotinic acetylcholine receptor $\alpha$-chain in mouse thymus. J. Immunol. 148:3105-3109.

16. Hara, H., K. Hayashi, K. Ohta, N. Itoh, and M. Ohta. 1993. Nicotinic acetylcholine receptor mRNAs in myasthenic thymuses: association with intrathymic pathogenesis of myasthenia gravis. Biochem. Biophys. Res. Commun. 194:1269-1275.

17. Marx, A., A. Wilisch, A. Schultz, A. Greiner, B. Magi, V. Pallini, B. Schalke, K. Toyka, W. Nix, T. Kirchner, and H.K. Müller-Hermelink. 1996. Expression of neurofilaments and of a titin epitope in thymic epithelial tumors: implications for the pathogenesis of myasthenia gravis. Amer. J. Pathol. 148: $1839-1850$.

18. Marx, A., A. Wilisch, A. Schultz, S. Gattentöhner, R. Nenninger, and H.K. Müller-Hermelink. 1997. Pathogenesis of myasthenia gravis. Virchows Archiv. 430:355-364.

19. Hawke, S., H. Matsuo, M. Nicolle, G. Malcherek, A. Melms, and N. Willcox. 1996. Autoimmune T cells in myasthenia gravis: heterogeneity and potential for specific immunotargeting. Immunol. Today. 17:307-311.

20. Sommer, N., N. Willcox, G.C. Harcourt, and J. Newsom-Davis. 1990 Myasthenic thymus and thymoma are selectively enriched in acetylcholine receptor-reactive T cells. Ann. Neurol. 28:312-319.

21. Hohlfeld, R., K.V. Toyka, S.J. Tzartos, W. Carson, and B.M. ContiTronconi. 1987. Human T-helper lymphocytes in myasthenia gravis recognize the nicotinic receptor alpha subunit. Proc. Natl. Acad. Sci. USA. 84:5379-5383.

22. Hawke, S., N. Willcox, G. Harcourt, A. Vincent, and J. Newsom-Davis. 1992. Stimulation of human T cells by sparse antigens captured on immunomagnetic particles. J. Immunol. Methods. 155:41-48.

23. Beeson, D., M. Brydson, H. Wood, A. Vincent, and J. Newsom-Davis. 1989. Human muscle acetylcholine receptor: cloning and expression in E. coli of cDNA for the $\alpha$-subunit. Biochem. Soc. Trans. 17:219-220.

24. Matsuo, H., A.-P. Batocchi, S. Hawke, M. Nicolle, L. Jacobson, A. Vincent, J. Newsom-Davis, and N. Willcox. 1995. Recognition of unnatural epitopes by peptide-selected $\mathrm{T}$ cell lines in myasthenia gravis patients and controls. J. Immunol. 155:3683-3692.

25. Willcox, N., F. Baggi, A.-P. Batocchi, D. Beeson, G. Harcourt, S. Hawke, L. Jacobson, H. Matsuo, A.-M. Moody, N. Nagvekar, et al. 1993. Approaches for studying the pathogenic T cells in autoimmune patients. Ann. NY Acad. Sci. 681:219-237.

26. Johnson, J.P., T. Meo, G. Riethmüller, D.J. Schendel, and R. Wank. 1982. Direct demonstration of an HLA-DR allotypic determinant on the low molecular weight (beta) subunit using a mouse monoclonal antibody specific for DR3. J. Exp. Med. 156:104-111.

27. Clarke, G.R., H. Reyburn, F.C. Lancaster, and A.W. Boylston. 1994. Bimodal distribution of $\mathrm{VB2}^{+} \mathrm{CD}^{+} \mathrm{T}$ cells in human peripheral blood. Eur. J. Immunol. 24:837-842.

28. Boylston, A.W., J. Borst, H. Yssel, D. Blanchard, H. Spits, and J. de Vries. 1986. Properties of a panel of monoclonal antibodies which react with the human T cell antigen receptor on the leukemic line HPB-ALL and a subset of normal peripheral blood T lymphocytes. J. Immunol. 137:741-744.

29. Beesley, J.E. 1993. Multiple immunolabelling techniques. In Immunocytochemistry, A Practical Approach. IRL Press at Oxford University Press, Oxford. $248 \mathrm{pp}$

30. Moss, P.A.H., W.M.C. Rosenberg, E. Zintzaras, and J.I. Bell. 1993. Characterization of the human T cell receptor $\alpha$-chain repertoire and demonstration of a genetic influence on V $\alpha$ usage. Eur. J. Immunol. 23:1153-1159.

31. Beeson, D., M. Amar, I. Bermudez, A. Vincent, and J. Newsom-Davis. 1996. Stable functional expression of the adult subtype of human muscle acetylcholine receptor following transfection of the human rhabdomyosarcoma cell line TE671 with cDNA encoding the $\epsilon$ subunit. Neurosci. Lett. 207:57-60.

32. Beeson, D., A.P. Bond, L. Corlett, S.J. Curnow, M.E. Hill, L.W. Jacobson, C. MacLennan, A. Meager, A.-M. Moody, P. Moss, et al. 1998. Thymus, thymoma and specific T cells in myasthenia gravis. Ann. NY Acad. Sci. In press.

33. Robbins, P.A., V.C. Maino, N.L. Warner, and F.M. Brodsky. 1988. Activated $\mathrm{T}$ cells and monocytes have characteristic patterns of class II antigen expression. J. Immunol. 141:1281-1287.

34. Gorga, J.C., V. Horejsi, D.R. Johnson, R. Raghupathy, and J.L. Strominger. 1987. Purification and characterization of class II histocompatibility antigens from a homozygous human B cell line. J. Biol. Chem. 262:1608716094.

35. Douek, D.C. 1997. MHC expression and selection events in the thymus. Ph.D. thesis. University of London, London. 335 pp.

36. Tzartos, S.J., M.T. Cung, P. Demange, H. Loutrari, A. Mamalaki, M Marraud, I. Papadouli, C. Sakarellos, and V. Tsikaris. 1991. The main immunogenic region (MIR) of the nicotinic acetylcholine receptor and the anti-MIR antibodies. Mol. Neurobiol. 5:1-29.

37. Vincent, A., P.J. Whiting, M. Schluep, F. Heidenreich, B. Lang, A. Roberts, N. Willcox, and J. Newsom-Davis. 1987. Antibody heterogeneity and specificity in myasthenia gravis. Ann. NY Acad. Sci. 505:106-120.

38. Nagvekar, N., L.W. Jacobson, N. Willcox, and A. Vincent. 1998 Epitopes expressed in myasthenia gravis (MG) thymomas are not recognized by patients' T cells or autoantibodies. Clin. Exp. Immunol. 112:17-20.

39. Moss, P.A.H., and J.I. Bell. 1995. Sequence analysis of the human $\alpha \beta$ T cell receptor CDR3 region. Immunogenetics. 42:10-18.

40. Takeuchi, Y., Y. Fujii, M. Okumura, K. Inada, K. Nakahara, and H. Matsuda. 1995. Accumulation of immature $\mathrm{CD}^{-} \mathrm{CD}^{+}{ }^{+} \mathrm{CD} 8^{-}$single-positive cells that lack CD69 in epithelial cell tumours of the human thymus. Cell. Immunol. 161:181-187.

41. Paliard, X., R. de W. Malefijt, J.E. de Vries, and H. Spits. 1988. Interleukin-4 mediates CD8 induction on human CD4 ${ }^{+}$T-cell clones. Nature. 335:642-644.

42. Berdoz, J., J. Gorski, A.-M. Termijtelen, J.-M. Dayer, C. Irlé, D. Schendel, and B. Mach. 1987. Constitutive and induced expression of the individual HLA-DR $\beta$ and $\alpha$ chain loci in different cell types. J. Immunol. 139:1336-1341.

43. Gilhus, N.-E., N. Willcox, G. Harcourt, N. Nagvekar, D. Beeson, A Vincent, and J. Newsom-Davis. 1995. Antigen presentation by thymoma epithelial cells from myasthenia gravis patients to potentially pathogenic T cells. $J$. Neuroimmunol. 56:65-76.

44. Vincent, A., N. Willcox, I. Roxanis, J. Newsom-Davis, C. MacLennan, and D. Beeson. 1997. Thymoma and autoimmune neurological disorders. A search for missing links in pathogenesis. In Epithelial Tumors of the Thymus; Pathology, Biology, Treatment. A. Marx, and H.K. Müller-Hermelink, editors. Plenum Publishing Corp., New York. 195-204.

45. Kääb, G., G. Brandl, A. Marx, H. Wekerle, and M. Bradl. 1996. The myelin basic protein-specific $\mathrm{T}$ cell repertoire in (transgenic) Lewis rat/SCID mouse chimeras: preferential V $\beta 8.2 \mathrm{~T}$ cell receptor usage depends on an intact Lewis thymic microenvironment. Eur. J. Immunol. 26:981-988.

46. Meager, A., A. Vincent, J. Newsom-Davis, and N. Willcox. 1997. Spontaneous neutralising antibodies to interferon- $\alpha$ and interleukin-12 in thymomaassociated autoimmune disease. Lancet (N. Am. Ed.). 350:1596-1597.

47. Shenoy, M., M. Oshima, M.Z. Atassi, and P. Christadoss. 1993. Suppression of experimental autoimmune myasthenia gravis by epitope-specific neonatal tolerance to synthetic region $\alpha$ 146-162 of acetylcholine receptor. Clin. Immunol. Immunopathol. 66:230-238.

48. Barkas, T., A. Mauron, B. Roth, C. Alliod, S. Tzartos, and M. Ballivet. 1987. Mapping the main immunogenic region and toxin binding site of the nicotinic acetylcholine receptor. Science. 235:77-80.

49. Fujii, Y., Y. Monden, K. Nakahara, J. Hashimoto, and Y. Kawashima. 1984. Antibody to acetylcholine receptor in myasthenia gravis: production by lymphocytes from thymus or thymoma. Neurology. 34:1182-1186.

50. Nicolle, M.W., B. Nag, S.D. Sharma, N. Willcox, A. Vincent, D.J.P. Ferguson, and J. Newsom-Davis. 1994. Specific tolerance to an acetylcholine receptor epitope induced in vitro in myasthenia gravis $\mathrm{CD}^{+}$lymphocytes by soluble major histocompatibility complex class II-peptide complexes. J. Clin. Invest. 93 : 1361-1369.

51. Bond, A.P., L. Corlett, S.J. Curnow, E. Spack, N. Willcox, and J. Newsom-Davis. 1998. Diverse patterns of unresponsiveness in an acetylcholine receptor-specific T-cell clone from a myasthenia gravis patient after engaging the T-cell receptor with three different ligands. J. Neuroimmunol. 82:182-190. 